\title{
Implementasi Kebijakan Value Added Tax Refund (Pengembalian PPN) bagi Perwakilan Diplomatik antara Negara Swedia dan Indonesia
}

\author{
Riani Dewi ${ }^{a *}$, Haula Rosdiana ${ }^{\mathrm{b}}$ \\ ${ }^{a b}$ Universitas Indonesia 'Salemba, Jakarta, Indonesia
}

\section{INFORMASI ARTIKEL}

\section{Article history:}

Dikirim tanggal: 19 Juni 2019

Revisi pertama tanggal: 23 Juli 2019

Diterima tanggal: 15 Desember 2019

Tersedia online tanggal: 30 Desember 2019

Keywords: tax policy, Value Added Tax (VAT), refund tax, tax

\section{ABSTRACT}

Tax policy in every country has difference outcome in implementation. The difference of policy in VAT (Value Added Tax) Refund process and other country, especially for Diplomatic Representatives is determined by the principle of reciprocity. The purpose of this study is to analyze policy of VAT Refund regulations between diplomatic representative for Sweden and Indonesia, also the adversity in the policy implementation. The analysis of tax refund process will be focused on the authority, tax objects, tax subjects, tax return processes. This type of research uses a qualitative method with a descriptive approach scope to analyze the implementation of VAT refund in Indonesia to all diplomatic representative. The Findings are the absence of a policy that regulates the time period for the process of tax returns for Diplomatic Representatives and the absence of an integrated online system between the Directorate General of Protocol and Consular, Diplomatic Representatives and Foreign Corporate \& Individual (Badora) Tax Service Office to facilitate and reduce human errors.

\section{INTISARI}

Kebijakan perpajakan pada setiap negara menghasilkan implementasi yang berbeda. Perbedaan kebijakan dalam proses pengembalian PPN antara Indonesia dengan negara lain, terutama untuk Perwakilan Diplomatik ditentukan berdasarkan asas resiprositas. Tujuan penelitian ini adalah untuk menganalisa implementasi kebijakan pengembalian pajak antara negara Swedia dan Indonesia bagi Perwakilan Diplomatik dan menganalisa kendala - kendala yang terjadi dalam pengimplementasian kebijakan tersebut. Analisa pengembalian pajak ini difokuskan pada kewenangan, objek pajak, subjek pajak, proses pengembalian pajak. Penelitian ini menggunakan metode kualitatif dengan pendekatan deskriptif dengan tujuan untuk menganalisa bagaimana proses pengembalian pajak di Indonesia untuk perwakilan diplomatik. Adapun kesimpulan dari penelitian ini adalah belum adanya kebijakan yang mengatur tentang jangka waktu proses pengajuan pengembalian pajak bagi Perwakilan Diplomatik dan belum adanya sistem online terintegrasi antara Direktorat Jenderal Protokol dan Konsuler, Perwakilan Diplomatik dan Kantor Pelayanan Pajak Badan dan Orang Asing untuk memudahkan dan mengurangi kesalahan dan human error. 


\section{Pendahuluan}

Pajak Pertambahan Nilai sebagai Pajak Tidak Langsung merupakan salah satu objek penerimaan negara yang dipungut berdasarkan undang - undang serta kebijakan yang berlaku pada suatu negara. Kebijakan perpajakan pada setiap negara satu dengan negara lain yang berbeda mengakibatkan perbedaan praktek dan implementasinya. Salah satu alasan perbedaan regulasi perpajakan setiap negara adalah setiap negara memiliki kebijakan untuk mengatur perekonomian dan iklim investasi yang akan berdampak pada kenaikan penerimaan negara itu sendiri.

Salah satu ketentuan yang menjadi acuan bagi dunia internasional dalam hal hubungan luar negeri adalah ketentuan - ketentuan yang ada di Konvensi Wina. Dalam peraturan tersebut mengatur mengenai perjanjian antar negara - negara yang tergabung dalam Perserikatan Bangsa - Bangsa dalam berinteraksi dan salah satunya membahas mengenai ketentuan perpajakan bagi perwakilan asing, diplomatik dan organisasi internasional.

Dalam Konvensi Wina pasal 34 dan 36 dijelaskan bahwa: "Pembebasan dari pajak untuk agen diplomatik dan Pembebasan dari Bea Cukai untuk misi diplomatik dan agennya serta keluarganya". Selanjutnya setiap negara membuat kebijakan dan peraturan untuk mengatur perlakuan perpajakan bagi Perwakilan Asing dan Organisasi Internasional di negara masing - masing sesuai dengan asas hukum Internasional.

Dalam pelaksanaan hukum Internasional sebagai bagian dari hubungan internasional, dikenal ada beberapa asas hukum yang didasarkan pada Konvensi Wina Tahun 1969 (UN, 2005), antara lain sebagai berikut:

a) Pacta Sunt Servanda, yaitu setiap perjanjian yang telah dibuat harus ditaati oleh pihak - pihak yang mengadakannya;

b) Equality Rights, yaitu negara yang saling mengadakan hubungan itu berkedudukan sama;

c) Reciprositas (Asas timbal-balik), yaitu tindakan suatu negara terhadap negara lain dapat dibalas setimpal, baik tindakan yang bersifat negatif atau pun posistif;

d) Courtesy, yaitu asas saling menghormati dan saling menjaga kehormatan masing-masing negara; dan

e) Rebus Sic Stantibus, yaitu asas yang dapat digunakan untuk memutuskan perjanjian secara sepihak apabila terdapat perubahan yang mendasar/ fundamental dalam keadaan yang bertalian dengan perjanjian internasional yang telah disepakati.

Dari kelima asas di atas penulis mengambil asas resiprositas (timbal balik) sebagai dasar dalam pelaksanaan perpajakan antara Perwakilan Asing dan Organisasi Internasional dikarenakan asas resiprositas adalah asas yang paling mewakili dalam penerapan ketentuan perpajakan bagi negara yang satu dengan negara yang lainnya.
Secara sederhana resiprositas adalah pertukaran timbal balik antar individu atau antar kelompok. Polyani (1944) memberi batasan resiprositas sebagai perpindahan barang atau jasa sacara timbal balik dari kelompokkelompok yang berhubungan secara simetris. Polyani (1944:48-49) mengungkapkan:

Reciprocity is enormous facilitated by the instituional pattern of symmetry, a frequent feature of social organization among non-literate peoples.

Dalam ungkapan tersebut dapat diartikan bahwa "Istilah Resiprositas sangat difasilitasi oleh pola institusional yang memiliki kesamaan dalam bagian bagian yang berada dalam organisasi sosial, kalangan masyarakat, non-terpelajar".

Dalam implementasi perpajakan pada Perwakilan Asing dan Organisasi Internasional tidak terlepas dari asas tersebut. Sehinga dalam penerapannya pemerintah membuat Peraturan tersendiri dan khusus untuk mengakomodir sesuai dengan Undang - Undang mengenai perpajakan yang berlaku.

Dalam penelitian ini, diambil tema mengenai Value Added Tax (VAT) Refund di Indonesia yang artinya pendapatan atas pengembalian pajak dari Pemerintah Indonesia karena mendapat fasilitas diplomatik berdasarkan asas resiprositas (timbal balik) diterima oleh Perwakilan RI sebagai Penerimaan Negara Bukan Pajak. VAT Refund tersebut dikategorikan sebagai penerimaan negara yang bersumber dari PNBP menurut "PP Nomor 49 Tahun 2016 tentang Jenis dan Tarif atas Jenis Penerimaan Negara Bukan Pajak yang berlaku di Kementerian Luar Negeri".

Pengenaan atas Value Added Tax atau Pajak Pertambahan Nilai (PPN) atas konsumsi barang dan jasa dikenakan pada setiap jalur produksi dan distribusi di setiap negara.

Pada penelitian ini, peneliti mengambil objek pada negara Swedia, karena apabila dibandingkan dengan negara - negara di Benua Eropa, Swedia merupakan salah satu negara yang memiliki tarif pajak tertinggi juga dibandingkan dengan negara - negara di kawasan Scandinavia lainnya.

Tabel 1 Perbandingan Tarif Pajak VAT di Negara - negara Eropa (\%)

\begin{tabular}{|c|c|c|c|c|c|}
\hline No. & Negara & Tarif & No. & Negara & Tarif \\
\hline 1. & Austria & 20 & 9. & Italy & 19 \\
\hline 2. & Belgia & 21 & 10. & Luxemburg & 15 \\
\hline 3. & Denmark & 25 & 11. & Belanda & 17,5 \\
\hline 4. & Finlandia & 24 & 12. & Portugal & 17 \\
\hline 5. & Perancis & 20,6 & 13. & Swedia & 25 \\
\hline 6. & Jerman & 15 & 14. & $\begin{array}{c}\text { United } \\
\text { Kingdom }\end{array}$ & 17,5 \\
\hline 7. & Yunani & 18 & 15. & Norwegia & 25 \\
\hline 8. & Irlandia & 21 & 16. & Islandia & 24 \\
\hline
\end{tabular}

Sumber: Hasil analisis, 2019 
Dalam tabel tersebut dapat diketahui bahwa Swedia merupakan negara - negara yang memiliki tarif VAT yang tertinggi dibandingkan negara Eropa lainnya.

Seiring perkembangan yang terjadi di Indonesia dan dunia internasional, akan diikuti pula oleh perubahan ketentuan dan peraturan dalam bidang perpajakan bagi perwakilan asing dan organisasi internasional. Perlakuan perpajakan bagi Perwakilan Asing dan diplomatik diatur melalui Peraturan khusus di setiap negara dengan menggunakan asas resiprositas sebagai acuan.

Salah satu ketentuan yang menjadi acuan bagi dunia internasional dalam hal hubungan luar negeri adalah ketentuan - ketentuan yang ada di Konvensi Wina. Dalam peraturan tersebut diatur mengenai perjanjian antar negara - negara yang tergabung dalam Perserikatan Bangsa - Bangsa dalam berinteraksi dan salah satunya membahas mengenai ketentuan perpajakan bagi perwakilan asing, diplomatik dan organisasi internasional.

Target penerimaan pengembalian pajak dapat dilihat dari besarnya anggaran yang ada pada setiap Perwakilan atau Kedutaan. Rincian anggaran setiap perwakilan dapat dilihat pada tabel sebagai berikut:

Tabel 2 Rekapitulasi Anggaran Negara Swedia Tahun 2017-2018

\begin{tabular}{|l|c|c|c|}
\hline \multicolumn{1}{|c|}{ Negara } & Tahun 2017 & Tahun 2018 & Naik \\
\hline Swedia & Rp33.125.91 & Rp36.853.182. & $11 \%$ \\
\hline
\end{tabular}

Sumber: Hasil analisis, 2019

Pada tabel tersebut, menjelaskan bahwa pada Tahun 2017 ke Tahun 2018, Swedia mengalami kenaikan anggaran. Hal itu akan meningkatkan pula konsumsi barang dan jasa pada setiap negara yang akan mengakibatkan meningkatnya pengembalian pajak pada negara tersebut.

Secara lebih lanjut apabila disimpulkan, negara Swedia mengalami kenaikan anggaran sebesar $11 \%$ dari Tahun 2017 ke Tahun 2018 atau sebesar Rp 3.727.269.000,00.

Namun kenyataannya pada realisasi penerimaan pengembalian pajak yang akan menjadi PNBP bagi Perwakilan tersebut mengalami penurunan, seperti yang ditampilkan pada tabel Rekapitulasi pengembalian pajak VAT (Value Added Tax) di Negara Swedia, sebagai berikut:

Tabel 3 Rekapitulasi Pengembalian VAT dari Negara SwediaTahun 2017-2018

\begin{tabular}{|c|c|c|c|}
\hline Negara & Tahun 2017 & Tahun 2018 & $\begin{array}{c}\text { Turun } \\
(\%)\end{array}$ \\
\hline Swedia & USD 124.429,93 & USD 122.953,60 & $-1 \%$ \\
\hline
\end{tabular}

Sumber: Hasil analisis, 2019
Menurut data rekapitulasi pengembalian VAT diatas, antara Tahun 2017 dan Tahun 2018 mengalami penurunan. Apabila dilihat dari adanya perubahan tarif pada tahun 2017-2018 tidak ditemukan adanya perubahan tarif karena masih menggunakan aturan dan kebijakan yang sama.

Tujuan penelitian adalah untuk menganalis perbandingan implementasi kebijakan Vat Refund (Pengembalian PPN) antara negara Swedia dengan Indonesia bagi Perwakilan Diplomatik dan untuk menganalis kendala implementasi kebijakan VAT Refund (Pengembalian PPN) antara negara Swedia dengan Indonesia bagi Perwakilan Diplomatik.

\section{Teori}

\subsection{Teori Kebijakan}

Kebijakan publik tidak muncul begitu saja namun harus melalui serangkaian tahapan agar kebijakan publik tersebut dapat terlaksana sesuai tujuannya. William Dunn mengatakan bahwa tahapan proses kebijakan publik secara teknis dapat dibedakan melalui lima tahapan, yaitu perumusan masalah, formulasi kebijakan, rekomendasi kebijakan, implementasi kebijakan, evaluasi kebijakan (Dunn, 2012). Tahapan Kebijakan Publik adalah sebagai berikut:

a) Perumusan masalah adalah "membantu menemukan asumsi - asumsi yang tersembunyi, mendiagnosis penyebab - penyebabnya, memetakan tujuan yang memungkinkan memadukan pandangan - pandangan yang bertentangan dan merancang peluang kebijakan baru";

b) Formulasi kebijakan adalah "peramalan dapat menyediakan pengetahuan yang relevan dengan kebijakan tentang masalah yang akan terjadi di masa datang sebagai akibat dari diamblnya alternatif, termasuk melakukan sesuatu. Peramalan dapat menguji masa depan yang potensial dan secara normatif bernilai, mengatasi akibat dari kebijakan yang ada yang diusulkan dan mengenali kendala kendala yang mungkin akan terjadi dalam pencapaian tujuan";

c) Rekomendasi kebijakan adalah "rekomendasi kebijakan membuahkan pengetahuan yang relevan dengan kebijakan tentang manfaat atau biaya dari berbagai alternatif yang akibatnya di masa mendatang telah diestimasi melalui waktu peramalan. Rekomendasi membantu mengestimasi tingkat resiko dan ketidakpastian, mengenali eksternalitas dan akibat ganda, menentukan kriteria dalam pembuatan pilihan dan menentukan pertanggungjawaban administrasi bagi implementasi kebijakan";

d) Implementasi kebijakan adalah "pemantauan atau monitoring menyediakan pengetahuan yang relevan 
dengan kebijakan mengenai akibat dari kebijakan yang diambil sebelumnya"; dan

e) Evaluasi Kebijakan adalah "membuahkan pengetahuan yang relevan dengan kebijakan tentang ketidaksesuaian antara kinerja kebijakan yang diharapkan dengan yang benar - benar dihasilkan. Evaluasi tidak hanya menghasilkan kesimpulan mengenai seberapa jauh masalah yang telah terselesaikan, tetapi juga menyumbang pada klarifikasi dan kritik terhadap nilai - nilai yang mendasari kebijakan, membantu dalam perubahan tingkatan dan perumusan kembali masalah".

Menurut Theodore dalam Pengantar Kebijakan Publik William N. Dunn, bahwa "menghasilkan informasi mengenai kinerja kebijakan digunakan tipe kriteria yang berbeda - beda untuk mengevaluasi hasil kebijakan" (Dunn, 2012). Dibawah ini adalah beberapa kriteria evaluasi:

a) Efektivitas adalah "berkenaan dengan apakah suatu kebijakan mencapai hasil yang diharapkan atau mencapai tujuan dari diadakannya tindakan. Efektivitas ini berkaitan dengan rasionalitas teknik, selalu diukur oleh unit produk atau layanan atau moneternya";

b) Efisiensi adalah "berkenaan dengan jumlah usaha yang diperlukan untuk menghasilkan tingkat efektifitas tertentu. Efisiensi adalah merupakan hubungan antara efektifitas dan usaha. Ukuran ukuran yang digunakan dalam kriteria efisiensi adlah jangka waktu pelaksanaan kebijakan, sumber daya manusia yang diberdayakan untuk melaksanakan kebijakan";

c) Kecukupan (adequacy) adalah "berkenaan dengan seberapa jauh suatu tingkat efektifitas memuaskan kebutuhan, nilai atau kesempatan yang menumbuhkan adanya masalah. Kriteria ini menekankan pada kuatnya hubungan antara alternatif kebijakan dan hasil yang diharapkan";

d) Kesamaan atau perataan (equity) adalah "berhubungan erat dengan rasionalitas legal dan sosial dan menunjuk pada distribusi akibat dan usaha antara kelompok - kelompok yang berbeda dalam masyarakat"; dan

e) Responsivitas adalah "bekenaan dengan seberapa jauh suatu kebijakan dengan memuaskan kebutuhan, preferensi, atau nilai kelompok - kelompok masyarakat tertentu".

Ketepatan (appropriateness) adalah "berhubungan dengan rasionalitas dan subtantif. Ketepatan merujuk pada nilai atau harga dari tujuan kebijakan dan kepada kuatnya asumsi yang melandasi tujuan tersebut".

\subsection{Konsep Value Added Tax (VAT)}

Prinsip Value Added Tax (VAT) yang dipakai oleh sebagian besar negara - negara di Eropa pada prinsipnya merupakan pajak yang dikenakan atas nilai tambah (Value Added). Menurut Tait (1988) pengertian Pajak Pertambahan Nilai, adalah sebagai berikut:

Value added is the value that a producer adds to his material or purchases (other than labor) before selling the new improved product or service. That are the inputs (the raw materials, transport, rent, advertising, and so on) are bought, people are paid wages to work on these inputs and, when the final good and service is sold, some profit is left. So, value added can be looked at from the additive side (wages plus profits) or from the subtractive side (wages plus profits) or from the subtractive side (output minus inputs).

Yang dimaksud nilai tambah ini merupakan nilai yang ditambahkan oleh produsen/ perusahaan untuk item - item atau pembelian (selain biaya untuk tenaga kerja) sebelum menjual produk atau jasa. Input yang ada (bahan - bahan, transportasi, iklan, dll) dibeli agar tenaga kerja dapat bekerja dengan input ini, dengan mengesampingkan keuntungan. Jadi nilai tambah dapat dilihat dari output dikurangi input.

Value added $=$ wages + profits $=$ output - input

Menurut Smith et al., (1973:3), Value added tax dapat didefinisikan sebagai:

The VAT is a tax on the value added by a firm to its products in the course of its operation. Value added can be viewed either as the difference between a firm's, sales and its purchase during an accounting period or as the sum of its wages, profits, rent, interest and other payment not subject to the tax during that period.

Dengan kata lain, Value added Tax adalah pajak atas adanya tambahan nilai oleh perusahaannya untuk produk dalam lingkup usahanya. Nilai tambah terlihat juga sebagai perbedaan sebuah entitasnya, penjualan dan pembelian selama periode pelaporan akuntansi atau sebagai total upah, keuntungan, sewa, bunga dan pembayaran lainnya yang dikecualikan dari pajak selama periode tersebut. Definisi tersebut dapat disimpulkan sebagai berikut:

Value added = sales - purchase

Value added $=$ wages + profits + rent + interest + other payment

Menurut Liam Ebrill et al., dalam bukunya The Modern VAT (2001) mendefinisikan Value Added Tax, adalah sebagai berikut:

Despite its name, the VAT is not generally intended to be a tax on value added as such rather it is usually intended as a tax on consumption. Its essence is that charged at all stages of production, but with the provision of some mechanism enabling firms to offset the tax they have paid on their own purchase 
of goods and services against the tax the charge on their sales of goods and services.

Dalam pernyataan tersebut disimpulkan bahwa Value Added Tax adalah pajak konsumsi yang semestinya dibebankan ke semua proses tahapan produksi dan tetap memperhitungkan kemampuan ekonomis yang memungkinkan atas pembelian barang dan jasa atas pajak dan biaya yang dikeluarkan.

\subsection{Kelebihan-Kelebihan Pajak Pertambahan Nilai}

Menurut Rosdiana \& Irianto (2012) dalam bukunya "Pengantar Ilmu Pajak Kebijakan dan Implementasi di Indonesia"; dipaparkan bahwa kelebihan - kelebihan dari Pajak Pertambahan Nilai, adalah sebagai berikut:

\section{a) Fiscal Advantages}

Bagi Pemerintah, terdapat beberapa keuntungan jika menerapkan VAT. "Pertama, karena cakupannya yang luas yang meliputi seluruh jalur produksi dan distribusi sehingga potensi pemajakannya juga besar. Kedua, karena sangat mudah untuk menimbulkan value added disetiap jalur produksi dan distribusi sehingga potensi pemajakannya semakin besar. Terakhir, dengan menggunakan sistem invoice (Faktur Pajak) lebih mudah untuk mengawasi pelaksanaan kewajiban perpajakan oleh wajib pajak serta mendeteksi adanya penyalahgunaan hak pengkreditan Pajak Masukan".

b) Psycological Advantages

"Karena pajak pada umumnya sudah dimasukkan kedalam harga jual/ harga yang dibayar oleh konsumen, maka seringkali konsumen tidak menyadari bahwa dia sudah membayar pajak. Hal ini berbeda dengan Pajak Penghasilan dimana pegawai, misalnya merasakan langsung beban pajak tersebut karena langsung mengurangi gaji yang diterimanya, sementara bila dia belanja di supermarket, karena dalam harga sudah termasuk PPN, dia tidak merasakan langsung bahwa dia membayar pajak".

c) Economic Advantages

"Seperti yang sudah dibahas dalam bab - bab sebelumnya, keunggulan dari consumption-based taxation adalah netral terhadap pilihan seseorang apakah akan saving terlebih dahulu ataukah langsung mengkonsumsikan penghasilan yang didapat".

\subsection{Fasilitas di Bidang Pajak Pertambahan Nilai}

Dalam menjalankan fungsinya sebagai instrumen untuk mengisi kas negara, pajak dikenakan secara netral kepada seluruh lapisan masyarakat, tanpa kecuali, sepanjang memenuhi persyaratan untuk dipajaki.

Akan tetapi, dalam menjalankan tugasnya untuk mengatur kehidupan bernegara, sifat netral ini dapat diabaikan. Artinya, ada sebagian golongan masyarakat yang mendapat keistimewaan untuk tidak dikenakan pajak. Langkah tersebut diambil sesuai dengan tujuan tujuan tertentu yang diinginkan pemerintah.

PPN dikenakan atas pertambahan nilai yang terjadi atas suatu barang atau jasa. Bahkan secara ideal, PPN pada dasarnya tidak menghendaki adanya pengecualian, pembebasan ataupun fasilitas. Namun untuk tujuan tujuan tertentu, PPN ini tidak dikenakan terhadap sektor - sektor tertentu. Inilah yang disebut dengan fasilitas.

Bentuk -bentuk fasilitas yang dapat diberikan pada PPN dapat berupa pembebasan dari pengenaan PPN (VAT Exemption) atau pengenaan tarif $0 \%$ (Zero Rating). Jika digambarkan dalam bentuk himpunan, maka kluster Barang Kena Pajak adalah sebagai berikut:

\section{Himpunan Barang}

Barang Tidak

Kena Pajak

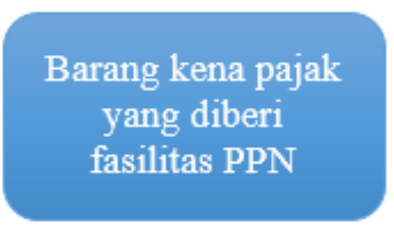

Gambar 1 Diagram Himpunan Barang

Sumber: Rosdiana, Irianto, \& Putranti, 2011

Berdasarkan Diagram diatas, maka dalam mendesain kebijakan taxable goods yang harus dirumuskan adalah kebijakan negative list (Barang Tidak Kena Pajak dan Barang Kena Pajak yang diberi fasilitas PPN). Pemberian fasilitas di bidang PPN dapat dibagi sebagai berikut:

a) Kebijakan Pembebasan PPN

Kebijakan pembebasan barang dari pengenaan PPN (VAT Exemption) menyebabkan tidak adanya PPN yang dikenakan pada saat terjadinya penyerahan. Hal ini menyebabkan pula PPN yang dikenakan pada saat pembelian bahan input produksi tidak dapat dikreditkan. Alasan diberikannya pembebasan PPN pada barang/ jasa tertentu dapat berupa alasan ekonomis, alasan sosial maupun alasan kemudahan administrasi. Pengusaha yang dibebaskan tidak perlu mendaftar ke otoritas pajak untuk keperluan PPN, sehingga pembebasan PPN juga membantu menyederhanakan administrasi dari PPN.

b) Kebijakan Pengenaan PPN Tarif 0\% (zero rating)

Kebijakan pengenaan tarif $0 \%$ ini menyebabkan dikenakannya tarif $0 \%$ pada saat terjadinya penyerahan barang/ jasa kena pajak. Yang membedakannya dengan pembebasan PPN adalah pajak masukan yang telah dibayarkan saat pembelian bahan input produksi dapat dikreditkan. Salah satu contoh penyerahan yang dikenakan tarif $0 \%$ adalah penyerahan ekspor. Hal ini dilakukan untuk memberikan insentif kepada para ekportir untuk menggiatkan kegiatan ekspor ke luar negeri. Dengan pengenaan tarif 0\% maka Pajak Keluarannya akan selalu nihil dan Pajak Masukannya dapat dikreditkan. 
Menurut Muhammad Rusjidi (2006), penerapan tax exmption dapat terlaksana untuk hal sebagai berikut:

a) Pembebasan objek PPN untuk peningkatan progresivitas PPN;

b) Barang dan jasa yang bersifat meritorious maka barang dan jasa tersebut layak untuk tidak dikenakan pajak; dan

c) Untuk beberapa barang dan jasa dianggap terlalu sulit untuk dikenakan pajak dan secara administrasi tidak perlu.

Pemberian pembebasan PPN akan memberikan kelebihan dan kekurangan. Kelebihannya adalah dapat menurunkan harga pasar produk yang dihasilkan, dapat meningkatkan demand apabila pembebasan tersebut diberikan ke konsumen akhir dan pembebasan PPN juga dapat memproteksi industri tertentu.

Kekurangannya adalah dapat mengurangi penerimaan negara dengan fasilitas tersebut juga dapat mendistorsi kegiatan ekonomi. Listrik adalah merid goods yang sangat dibutuhkan oleh masyarakat, sehingga pemberian fasilitas pembebasan PPN sangat layak diberikan.

Kebijakan pemberian fasilitas pembebasan PPN bagi Wajib Pajak menjadi keuntungan dalam hal cash flow perusahaan. Dana yang harusnya disetorkan ke negara untuk pembayaran PPN dapat digunakan sebagai penambah investasi.

Penelitian ini menggunakan teori - teori pada penelitian terdahulu antara lain.

Tabel 4 Matriks literatur perbandingan terdahulu

\begin{tabular}{|c|c|c|c|c|}
\hline Judul & $\begin{array}{l}\text { Pengaruh } \\
\text { Pajak } \\
\text { Pertambahan } \\
\text { Nilai, Efek dan } \\
\text { Implikasinya }\end{array}$ & $\begin{array}{l}\text { Perbandingan } \\
\text { Sistem Pajak } \\
\text { Pertambahan } \\
\text { Nilai di Negara } \\
\text { Rusia dan China. }\end{array}$ & $\begin{array}{l}\text { Pemberian } \\
\text { Restitusi/ } \\
\text { Pengembalian } \\
\text { PPN atas BKP } \\
\text { Ekspor apabila } \\
\text { dilihat dari } \\
\text { Hubungan } \\
\text { Kerja DJP } \\
\text { dengan DJBC }\end{array}$ & $\begin{array}{l}\text { Analisis Kebijakan } \\
\text { Restitusi/ } \\
\text { Pengembalian PPN } \\
\text { bagi Pemegang } \\
\text { WNA/ Paspor LN } \\
\text { (Nonresident) }\end{array}$ \\
\hline Penulis & $\begin{array}{l}\text { Obeng, George } \\
\text { (2018). } \\
\text { University of } \\
\text { Education, } \\
\text { Winneba, } \\
\text { Ghana }\end{array}$ & 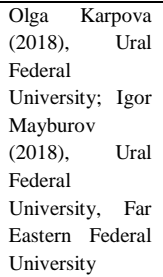 & $\begin{array}{l}\text { Parismatua L. } \\
\text { Tobing (2006), } \\
\text { Mahasiswa } \\
\text { Universitas } \\
\text { Indonesia. }\end{array}$ & $\begin{array}{l}\text { Enggar Sawitri } \\
\text { Widyastuti (2009), } \\
\text { Mahasiswa } \\
\text { Universitas } \\
\text { Indonesia }\end{array}$ \\
\hline Teori & $\begin{array}{l}\text { Pajak } \\
\text { Pertambahan } \\
\text { Nilai }\end{array}$ & $\begin{array}{l}\text { Pajak } \\
\text { Pertambahan } \\
\text { Nilai }\end{array}$ & $\begin{array}{l}\text { Pajak } \\
\text { Pertambahan } \\
\text { Nilai, Restitusi }\end{array}$ & $\begin{array}{l}\text { Pajak Pertambahan } \\
\text { Nilai, Kebijakan } \\
\text { Publik }\end{array}$ \\
\hline $\begin{array}{l}\text { Pendekatan } \\
\text { Penelitian }\end{array}$ & $\begin{array}{l}\text { Metode } \\
\text { Kualitatif }\end{array}$ & $\begin{array}{l}\text { Metode } \\
\text { Kualitatif }\end{array}$ & $\begin{array}{l}\text { Metode } \\
\text { Kualitatif }\end{array}$ & Metode Kualitatif \\
\hline $\begin{array}{l}\text { Tujuan } \\
\text { Penelitian }\end{array}$ & $\begin{array}{l}\text { Untuk } \\
\text { menganalisa } \\
\text { Pengaruh PPN, } \\
\text { Efek dan } \\
\text { Implikasinya } \\
\text { dikarenakan } \\
\text { perdebatan } \\
\text { mengenai } \\
\text { kekhawatiran } \\
\text { PPN bersifat } \\
\text { inflasi, } \\
\text { Implikasi dari } \\
\text { literatur dan } \\
\text { studi yang } \\
\text { tersedia } \\
\text { menunjukkan } \\
\text { fakta bahwa } \\
\text { PPN dapat }\end{array}$ & $\begin{array}{l}\text { Untuk } \\
\text { menganalisa } \\
\text { perpajakan di } \\
\text { negara Rusia dan } \\
\text { China, } \\
\text { khususnya } \\
\text { mengenai Pajak } \\
\text { Pertambahan } \\
\text { Nilai karena } \\
\text { proses integrasi } \\
\text { dan kerjasama } \\
\text { China dan Rusia } \\
\text { berkembang } \\
\text { pesat. }\end{array}$ & $\begin{array}{l}\text { Untuk } \\
\text { menguraikan } \\
\text { dan } \\
\text { menganalisis } \\
\text { kesesuaian } \\
\text { sistem dan } \\
\text { prosedur } \\
\text { restitusi PPN } \\
\text { atas barang } \\
\text { ekspor oleh DJP } \\
\text { dan untuk } \\
\text { menganalisis } \\
\text { DJBC dalam } \\
\text { melaksanakan } \\
\text { ekspor sudah } \\
\text { sesuai dengan } \\
\text { sistem dan }\end{array}$ & $\begin{array}{l}\text { Untuk menjelaskan } \\
\text { latar belakang } \\
\text { pemerintah } \\
\text { memberlakukan } \\
\text { kebijakan restitusi } \\
\text { PPN bagi pemilik } \\
\text { paspor LN dan } \\
\text { mendeskripsikan } \\
\text { implementasi } \\
\text { restitusi PPN dan } \\
\text { kendala yang } \\
\text { dihadapi di negara } \\
\text { Jerman, Singapura } \\
\text { dan Indonesia. }\end{array}$ \\
\hline
\end{tabular}

\begin{tabular}{|c|c|c|c|c|}
\hline Judul & $\begin{array}{l}\text { Pengaruh } \\
\text { Pajak } \\
\text { Pertambahan } \\
\text { Nilai, Efek dan } \\
\text { Implikasinya }\end{array}$ & $\begin{array}{l}\text { Perbandingan } \\
\text { Sistem Pajak } \\
\text { Pertambahan } \\
\text { Nilai di Negara } \\
\text { Rusia dan China. }\end{array}$ & $\begin{array}{l}\text { Pemberian } \\
\text { Restitusi/ } \\
\text { Pengembalian } \\
\text { PPN atas BKP } \\
\text { Ekspor apabila } \\
\text { dilihat dari } \\
\text { Hubungan } \\
\text { Kerja DJP } \\
\text { dengan DJBC }\end{array}$ & $\begin{array}{l}\text { Analisis Kebijakan } \\
\text { Restitusi/ } \\
\text { Pengembalian PPN } \\
\text { bagi Pemegang } \\
\text { WNA/ Paspor LN } \\
\text { (Nonresident) }\end{array}$ \\
\hline & $\begin{array}{l}\text { berdampak } \\
\text { negatif pada } \\
\text { produksi dan } \\
\text { konsumsi, } \\
\text { menghambat } \\
\text { aliran bebas } \\
\text { kegiatan } \\
\text { ekonomi. }\end{array}$ & & $\begin{array}{l}\text { prosedur yang } \\
\text { ditetapkan. }\end{array}$ & \\
\hline $\begin{array}{l}\text { Hasil } \\
\text { Penelitian }\end{array}$ & 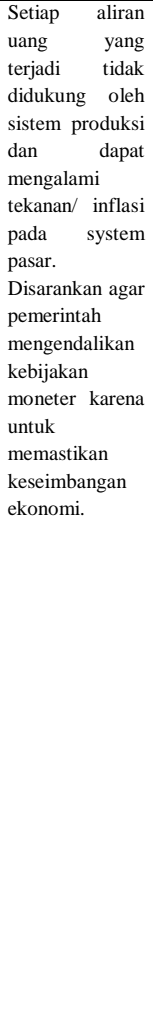 & 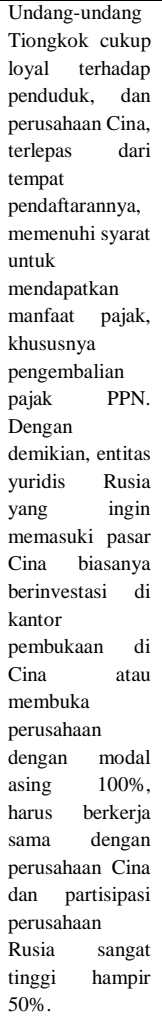 & $\begin{array}{l}\text { Banyaknya } \\
\text { pemberian } \\
\text { restitusi fiktif } \\
\text { dikarenakan } \\
\text { kurangnya } \\
\text { harmonisasi } \\
\text { antar } \quad \text { (dua) } \\
\text { instansi } \\
\text { pemerintah } \\
\text { yaitu DJP dan } \\
\text { DJBC. Dalam } \\
\text { memproses } \\
\text { restitusi PPN } \\
\text { kewenangan } \\
\text { DJP hanya } \\
\text { sebatas } \\
\text { memeriksa } \\
\text { kelengkapan } \\
\text { data yang } \\
\text { diberikan wajib } \\
\text { pajak, namun } \\
\text { kewenangan } \\
\text { memverifikasi } \\
\text { fisik barang } \\
\text { merupakan } \\
\text { kewajiban } \\
\text { DJBC tetapi } \\
\text { seringkali } \\
\text { memakan waktu } \\
\text { dan menjadi } \\
\text { kendala. }\end{array}$ & $\begin{array}{l}\text { Kebijakan ini sudah } \\
\text { berlaku di Jerman } \\
\text { dan Singapura. } \\
\text { Kebijakan ini } \\
\text { dimaksudkan untuk } \\
\text { menggiatkan } \\
\text { kegiatan konsumsi } \\
\text { di dalam negeri oleh } \\
\text { nonresident } \\
\text { tersebut. Kendala } \\
\text { penerapan } \\
\text { kebijakan ini bagi } \\
\text { Indonesia secara } \\
\text { umum adalah } \\
\text { memberlakukan } \\
\text { kebijakan ini untuk } \\
\text { barang - barang } \\
\text { industri UMKM. }\end{array}$ \\
\hline
\end{tabular}

Sumber: Hasil analisis, 2019

Dari tabel tersebut dapat dilihat bahwa penelitian penelitian sebelumnya mengenai Pajak Pertambahan Nilai dan restitusi dan perbandingan kebijakan pada negara - negara Rusia dan China. Dalam penelitian ini, peneliti melakukan penelitian yang berbeda dengan yang sebelumnya yaitu mengenai kebijakan VAT refund (pengembalian PPN) yang menjadikan perwakilan diplomatik sebagai perbandingan.

\section{Metode Penelitian}

Teknik analisis yang digunakan guna menjawab research question adalah analisis deskriptif kualitatif dalam menganalisis (a) Sejauh mana implementasi kebijakan pengembalian pajak antara Swedia dan Indonesia bagi Perwakilan diplomatik; dan (b) Kendala dalam implementasi kebijakan pengembalian pajak tersebut.

Metode yang digunakan dalam pencarian data dan informasi adalah studi literatur dan penelaahan data sekunder. Menurut Sekaran (2009), data sekunder adalah 
data yang diperoleh secara tidak langsung, berupa keterangan yang ada hubungannya dengan penelitian. Data sekunder diperoleh melalui dokumen resmi pemerintahan, akses internet serta data online.

Selain itu juga data yang diperoleh dari situs resmi pemerintah Indonesia dan Swedia seperti Kementerian Luar Negeri, Kementerian Keuangan, Skatterverket. Demikian juga informasi didapat dari penggalian beberapa informasi yang berasal dari berbagai sumber makalah serta didukung pula dengan kajian pustaka.

\section{Hasil Penelitian dan Pembahasan}

\subsection{Proses Implementasi Pengembalian Pajak PN di Indonesia untuk Perwakilan Diplomatik}

Peraturan mengenai perpajakan bagi Perwakilan Asing dan Organisasi Internasional di Indonesia diatur melalui kebijakan "PMK RI Nomor 161/PMK.03/2014 tentang Tata Cara Pengembalian Pajak Pertambahan Nilai atau Pajak Pertambahan Nilai dan Pajak Penjualan atas Barang Mewah yang telah dipungut kepada Perwakilan negara asing dan Badan Internasional serta pejabatnya" dan "Peraturan Direktur Jenderal Bea dan Cukai nomor PER-23/BC/2016 tentang Petunjuk pelaksanaan pemberian pembebasan Bea Masuk dan/ atau Cukai serta penyelesaian kewajiban pabean atas impor barang perwakilan negara asing beserta pejabatnya yang bertugas di Indonesia". Dalam kebijakan tersebut dijelaskan bahwa atas pembebasan pajak setiap negara ditentukan berdasarkan asas resiprositas dan kebijakan tersebut ditetapkan oleh Menteri Luar Negeri.

a) Subjek Pajak dan Objek Pajak

Dalam kebijakan tersebut dijelaskan bahwa Pajak Pertambahan Nilai atau Pajak Penjualan atas Barang Mewah yang terutang atas impor barang kena pajak dan/ atau jasa kena pajak yang telah dipungut pada Perwakilan Negara Asing serta Pejabat Perwakilan Negara Asing atau Badan Internasional, dapat dimintakan pengembalian atas pajaknya. PPN atau PPN BM yang terutang atau perolehan kendaraan bermotor dan telah dipungut dari Perwakilan Negara Asing atau Badan Internasional serta pejabatnya dapat dimintakan pengembalian jika memenuhi persyaratan sebgaimana diatur dalam PMK tentang tata cara penerbitan surat Keterangan Bebas Pajak Pertambahan Nilai atau Pajak Penjualan atas Barang Mewah kepada Perwakilan Asing atau Badan Internasional.

b) Kriteria Pajak yang mendapat pengembalian

Proses pengembalian Pajak Pertambahan Nilai dan Pajak Penjualan Barang Mewah yang telah dipungut oleh Perwakilan Diplomatik dilakukan berdasarkan asas resiprositas atau timbal balik. Pengembalian PPN dan PPN BM tersebut juga nilai minimal untuk harga pembelian BKP atau JKP yang telah ditetapkan.
Dengan tambahan ketentuan (minimum purchase requirement) setiap negara dari Menteri Luar Negeri atau pejabat yang ditunjuk.

c) Prosedur Permintaan Pengembalian Pajak

Perwakilan Diplomatik pada prosesnya mengajukan pengembalian paling lama 1 (satu) tahun sejak impor barang kena pajak atau penyerahan jasa/ barang kena pajak di Indonesia. Perwakilan Diplomatik dapat mengajukan surat permintaan pengembalian Pajak Pertambahan Nilai dan PPN BM atas impor BKP atau penyerahan BKP dan JKP yang dilakukan lebih dari 1 (satu) tahun dengan ketentuan yaitu permintaan pengembalian dimaksud tidak lebih dari 4 (empat) tahun sejak impor BKP atau penyerahan BKP dana tau JKO yang dilengkapi dengan pertimbangan dari Menteri Luar Negeri atau pejabat yang ditunjuk.

Pengembalian PPN dan PPN BM hanya diberikan kepada Badan Internasional yang tidak termasuk sebagai subjek Pajak Penghasilan sebagaimana diatur dalam ketentuan peraturan perundang - undangan di bidang Pajak Penghasilan. Pengembalian PPN atau PPN BM dapat dilakukan paling lama satu tahun sejak tanggal kuitansi atau pembelian untuk pembelian barang dan jasa impor.

Proses pengembalian PPN atau PPN BM dengan mempertimbangkan nilai minimal atas penyerahan barang mewah dilakukan dengan mempertimbangkan nilai minimum pembelian BKP atau JKP di luar PPN yang ditetapkan suatu negara (minimum purchase requirement) oleh Menteri Sekretaris Negara atau pejabat yang ditunjuk. Perwakilan diplomatik mengajukan surat permintaan pengembalian PPN atau PPN BM kepada Menteri Keuangan melalui Menteri Luar Negeri atau Menteri Sekretaris Negara.

Kemudian Menteri Luar Negeri atau Menteri Sekretaris Negara atau yang ditunjuk menyampaikan surat permohonan pengembalian Pajak Pertambahan nilai dan Pajak Penjualan atas Barang Mewah kepada Kepala Kantor Pajak dan Orang Asing dengan melampirkan surat rekomendasi dari Kementerian Luar Negeri atau Sekretariat Negara serta melampirkan bukti dan dokumen pendukung yaitu asli faktur pajakdan/ atau asli dokumen yang dipersamakan dengan faktur pajak, bukti dan atau dokumen pembayaran, dan bukti yang dipersyaratkan oleh Kementerian Luar Negeri dan Sekretariat Negara. Disamping bukti dukung tersebut, dalam hal pembelian kendaraan bermotor harus dilengkapi pula dengan surat pernyataan jumlah kepemilikan kendaraan bermotor, atau transaksi selain eceran, harus dilengkapi dengan fotokopi kontrak perjanjian atau dokumen yang dipersamakan.

Kepala KPP Badan dan Orang Asing akan melakukan penelitian terhadap berkas pengajuan pengembalian pajak dari Perwakilan Diplomatik kemudian memberikan keputusan paling lama dalam 30 
(tiga puluh) hari sejak permohonan pengembalian diterima secara lengkap.

Apabila berkas yang diajukan belum lengkap, maka perwakilan diplomatik diberikan surat permintaan dengan tembusan ke Kementerian Luar Negeri cq. Sekretariat Negara. Penyelesaian proses pengembalian, dapat dilakukan tanpa menunggu jawaban konfirmasi faktur pajak atau dokumen yang dipersamakan dengan faktur pajak terlebih dahulu.

Konfirmasi faktur atau dokumen lain yang dipersamakan sebagai faktur pajak dilakukan dengan mengirimkan fotokopi faktur pajak atau dokumen lain ke KPP di tempat PKP yang menerbitkan faktur pajak terdaftar. Apabila jangka waktu terlewati dan KPP Badan dan Orang Asing tidak memberikan keputusan makan permohonan pengembalian tersebut dianggap dikabulkan dan permohonannya pengembalian pajaknya dikabulkan.

KPP Badan dan Orang Asing menerbitkan Surat Ketetapan Pajak Lebih Bayar (SKPLB) paling lama satu bulan setelah jangka waktu tersebut berakhir. Importir, distributor, dealer, agen, penyalur, showroom, atau pihak lainnya melakukan penyerahan kendaraan bermotor kepada Perwakilan Diplomatik dengan mengajukan permohonan pengembalian pajak, dalam hal ini permohonan atas pengembalian pajaknya telah dibayar atau telah dipungut sebelumnya dan telah memiliki Surat Keterangan Bebas Pajak Penjualan atas Barang Mewah telah disetor ke Kas Negara.

Permohonan pengembalian pajak diajukan ke Direktorat Jenderal Pajak c.q. Kepala Kantor Pelayanan Pajak tempat pemohon dengan dilengkapi bukti - bukti pendukung seperti fotokopi NPWP, fotokopi Bukti Kepemilikan Kendaraan Bermotor (BPKP), fotokopi Surat Tanda Nomor Kendaraan (STNK), Asli dan fotokopi faktur pajak dari penjual missal dari pabrikan kepada distributor/ dealer/ agen/ penyalur/ showroom yang didalamnya dicantumkan Pajak Penjualan yang telah dipungut, dan khusus untuk kendaraan bermotor eks impor kendaraan dalam keadaan jadi/ completely built up (CBU), dilengkapi dengan surat keterangan yang memuat nama, alamat, dan NPWP importir kendaraan bermotor yang diterbitkan penjual kendaraan bermotor. Proses pengajuan harus dilakukan paling lama 12 (dua belas) bulan setelah terjadinya penyerahan atas kendaraan bermotor. Kepala Kantor Pelayanan pajak setempat tempat pemohon harus menerbitkan surat ketetapan minimal dalam tiga bulan sejak berkas diterima lengkap.

\subsection{Contoh Proses Pengembalian Pajak untuk Negara Swedia}

Berdasarkan data yang diperoleh dari Direktorat Fasilitas Diplomatik Direktorat Jenderal Protokol dan Konsuler Kementerian Luar Negeri; daftar barang dan jasa yang tidak bisa di-refund oleh negara Swedia berdasarkan asas resiprositas adalah sebagai berikut: a) Kebutuhan sehari - hari (daging, sayur mayor, buah buahan, masakan kemasan, kebutuhan pokok, pakaian, sepatu, tas, koper, perhiasan);

b) Perabot rumah tangga (benda - benda seni, pajangan, lukisan, peralatan makan, alat - alat kebersihan);

c) Alat tulis dan perlengkapan kantor (kertas, pulpen, pensil, tipe ex, stapler, map);

d) Pembayaran PBB, BPHTB, IMB;

e) Domestik/ International Flights (airport tax, tiket, dan sebagainya).

f) Bunga bank; dan

g) Pajak hotel dan restoran kecuali resepsi hari nasional. Sedangkan untuk ketentuan pajak di Swedia bagi Perwakilan Asing dan Diplomatik diatur berdasarkan Guidelines for diplomatic missions, career consulates and international organizations. Daftar barang dan jasa yang tidak dapat di-refund bagi negara Indonesia adalah sebagai berikut:

a) Barang dan jasa selain dari perwakilan asing;

b) Barang - barang konsumsi (food, baterai, bola lampu, lampu pijar, botol gas, rangkaian bunga, kertas, pulpen, file, produk kebersihan, filter, cartridges untuk mesin foto copy, pita, piring dan tissue kertas, lilin, dan seterusnya);

c) Kaset, USB, Compact Disc, Video Tapes, unexposed and exposed film, kertas fotocopy, chemicals dan yang berhubungan dengan fotografi dan film, tas;

d) Kapal, Tenda, Keperluan Olahraga, Binatang;

e) Sewa parkir dan garasi;

f) Pelayanan informasi, iklan, pelayanan konsultan, pendidikan, pelayanan hukum, pelayanan pos dan kurir;

g) Jasa perjalanan, lodging, sewa atau pembelian caravan, jasa transportasi, jasa pindahan, VIP dan jasa pelayanan bandara; dan

h) Kuitansi rumah makan/ restoran, jasa catering, sewa diluar kedutaan.

Menurut hasil pengecekan matriks pengembalian pajak yang dilakukan disimpulkan bahwa antara Kementerian Luar Negeri telah melakukan verifikasi berdasarkan asa resiprositas (timbal balik) sehingga untuk mengurangi kerugian negara atas perbedaan kebijakan.

Pembaharuan matriks pengembalian pajak setiap negara dilakukan setiap tahunnya guna untuk mengantisipasi perubahan yang terjadi pada setiap negara. Jika tedapat pengajuan pengembalian pajak yang tidak sesuai dengan matriks pengembalian akan ditolak.

Apabila dilihat secara lebih lanjut terdapat kriteria yang berbeda - beda untuk mengevaluasi hasil kebijakan menurut Dunn, yaitu efektifitas (effectivity), efisiensi (efficiency), kecukupan (adequacy), responsivitas (responsiveness), dan ketepatan (appropriateness). Evaluasi proses pengembalian pajak pada perwakilan 
diplomatik di Indonesia dapat menggunakan kriteria tersebut, yaitu sebagai berikut:

a) Efektivitas

Kriteria evaluasi yang pertama menurut Dunn adalah efektifitas. Efektifitas yang digunakan adalah dengan melihat apakah hasil yang diinginkan dari suatu kebijakan telah terealisasi. Apabila dilihat dalam kriteria ini, proses implementasi kebijakan pengembalian pajak telah sesuai dengan asas resiprositas yaitu dengan melakukan pengecekan pada setiap pengajuan pengembalian pajak dari Perwakilan Diplomatik.

b) Efisiensi

Kriteria evaluasi yang kedua adalah efisiensi. Evaluasi dari perspektif efisiensi untuk melihat seberapa banyak usaha yang diperlukan untuk mencapai hasil yang diinginkan. Kriteria efisiensi dilihat dari dua sisi yaitu sisi fiskus dan sisi wajib pajak. Komponen cost of taxation tidak hanya meliputi biaya yang dapat diukur dengan uang tetapi juga biaya yang tidak dapat diukur dengan uang (tangible cost). Proses pengembalian pajak dilihat dari kriteria efisiensi, belum adanya aturan atau penjelasan mengenai jangka waktu maksimal yang wajib dipenuhi oleh Kementerian Luar Negeri atas setiap pengajuan pengembalian pajak dari Perwakilan Diplomatik. Berbeda dengan KPP Badan dan Orang Asing yang telah menetapkan jangka waktu, yaitu sebesar 30 (tiga puluh) hari setelah pengajuan pengembalian pajak. Pada proses ini juga belum adanya sistem aplikasi yang terhubung dengan sistem perpajakan di Indonesia, sehingga setiap pengecekan harus dilakukan manual dengan resiko human error pada saat pengecekan.

c) Kecukupan

Kriteria selanjutnya adalah kecukupan (adequacy), yaitu seberapa jauh pencapaian hasil yang diinginkan dari kebijakan dalam memecahkan suatu masalah. Apabila dilihat pada kriteria kecukupan (adequacy), proses kebijakan pengembalian pajak untuk perwakilan diplomatik di Indonesia belum menggunakan aplikasi karena masih dilakukan dengan manual. Proses untuk pengecekan dilakukan dengan memverifikasi semua pengajuan dari seluruh kedutaan kemudian melakukan pengecekan berdasarkan asas resiprositas (timbal balik) setelah dilakukan verifikasi Ditjen Protokol Konsuler Kemenlu melakukan persetujuan untuk diteruskan ke Kementerian Kauangan dalam hal ini ditangani oleh KPP Badan dan Orang Asing Jakarta.

d) Kesamaan

Selain itu kriteria evaluasi kebijakan keempat mengacu pada adanya persamaan atau pemerataan (equity). Pada kriteria ini dijelaskan bahwa berhubungan erat dengan rasionalitas legal dan sosial dan menunjuk pada distribusi akibat dan usaha antara kelompok - kelompok yang berbeda dalam masyarakat dan pada kriteria ini pajak harus bebas dari distorsi terhadap distorsi terhadap konsumsi maupun distorsi terhadap produksi serta faktor ekonomi yang lainnya. Pada kriteria keempat ini terlihat pada setiap proses pengajuan pengembalian pajak diberlakukan sama untuk semua perwakilan diplomatik baik dari verifikasi maupun dari persetujuannya. Setiap proses pengajuan diverifikasi melalui matriks resiprositas untuk masing - masing negara.

e) Responsivitas

Kriteria kelima adalah responsivitas, yaitu bekenaan dengan seberapa jauh suatu kebijakan dengan memuaskan kebutuhan, preferensi, atau nilai kelompok - kelompok masyarakat tertentu, dalam hal ini objek responsivitas kebijakan adalah perwakilan diplomatik. Berdasarkan pengamatan, seluruh perwakilan diplomatik melaksanakan kebijakan pengembalian pajak sesuai dengan prosedur yang ada.

f) Ketepatan

Kriteria evaluasi kebijakan yang terakhir adalah ketepatan (appropriateness), yaitu penilaian apakah hasil yang diinginkan (tujuan) benar - benar berguna/ bernilai bagi pihak yang menjadi target kebijakan atau dapat juga yang berhubungan dengan rasionalitas dan subtantif. Pada prakteknya pada sisi waktu belum adanya prosedur yang memberikan kepastian mengenai berapa lama proses yang akan ditempuh pada saat proses pengajuan pengembalian pajak baik itu di Direktorat Jenderal Protokol dan Konsuler Kementerian Luar Negeri maupun pada KPP Badan dan Orang Asing. Akibat belum adanya ketepatan ini pihak Perwakilan Diplomatik hanya menunggu berdasarkan konfirmasi dari kedua instansi tersebut.

\section{Kesimpulan}

Berdasarkan penelitian dan analisa yang diperoleh dapat diambil beberapa kesimpulan. Secara umum implementasi kebijakan pengembalian pajak bagi perwakilan diplomatik di Indonesia masih belum berjalan optimal, hal ini disebabkan oleh beberapa hal, yaitu sebagai berikut:

a) Belum adanya kebijakan yang mengatur tentang jangka waktu proses pengajuan pengembalian pajak bagi perwakilan diplomatik; dan

b) Belum adanya sistem online terintegrasi antara Direktorat Jenderal Protokol dan Konsuler, Perwakilan Diplomatik dan KPP Badan dan Orang Asing untuk memudahkan dan mengurangi human error.

Berdasarkan kesimpulan diatas, dapat diberikan saran sebagai berikut: 
a) Perlu dilakukannya revisi kebijakan atau aturan mengenai jangka waktu yang dibutuhkan dalam proses pengajuan pengembalian pajak untuk perwakilan diplomatik; dan

b) Perlu dikembangkan sistem online terintegrasi guna memudahkan dan mengurangi human error antara Direktorat Jenderal Protokol dan Konsuler, Perwakilan Diplomatik dan KPP Badan dan Orang Asing.

\section{Daftar Pustaka}

Dunn,William. (2012). Public Policy Analysis. New York: Routledge.

Ebrill, Liam P., Michael Keen., Jean-Paul Bodin., \& Victoria J Perry. (2001). The Modern VAT. Washington: International Monetary Fund.

Polyani, Karl. (1944). The Great Transformation. AS: Farrar \& Rinehart.

Rosdiana, Haula., Irianto, E.S., \& Putranti, T.M. (2011). Teori Pajak Pertambahan Nilai. Bogor: Ghalia Indonesia.

Rosdiana, Haula., \& Edi Slamet Irianto. (2012). Pengantar Ilmu Pajak: Kebijakan dan Implementasi, Jakarta: Raja Grafindo Persada.

Rusjidi, Muhammad. (2006). Pajak Pertambahan Nilai dan Pajak Penjualan atas Barang Mewah, Edisi Ketiga. Jakarta: PT. Indeks.

Smith, Dan Throop., James B Webber., \& Carol M Cerf. (1973). What you should know about the VAT. Illnois: Down Jones-Irwin, Inc.

Taut, Alan A. (1988). Value Added Tax: International Practice and Problems. Washington: International Monetary Fund.

UN. (2005). Vienna Convention on the Law of Treaties (1969). New York: UN. 